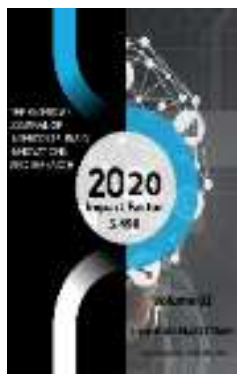

Journal Website: http://usajournalshub.c om/index,php/tajiir

Copyright: Original content from this work may be used under the terms of the creative commons attributes 4.0 licence.

\section{The Importance Of Relating Mathematical Problems With Other Subjects In The Formation Of Student's Research Skills}

\author{
Muqadasova Odina Ikhtiyorjon Qizi \\ Master, Faculty Natural Sciences, Named After Nizami TSPU, Tashkent,Uzbekistan \\ Shodmonkulova Shakhnoza Mirvali Qizi \\ 4th Year Student Majoring In Mathematics Teaching Methods, Named After Nizami TSPU, \\ Tashkent, Uzbekistan \\ Xusanboyeva Zulfizar Xayrulla Qizi \\ 4th Year Student Majoring In Mathematics Teaching Methods, Named After Nizami TSPU, \\ Tashkent, Uzbekistan
}

\title{
ABSTRACT
}

In this article, you will learn about the importance of linking mathematics to other disciplines. Teaching science in conjunction with a variety of disciplines shapes and enhances a student's ability to research. Any of the lessons using the questions and questions listed below will help students learn more. Because repetition strengthens knowledge. And solid knowledge is the foundation of the future. In this, the importance of mathematics is great. As the great scientist Lobachevsky said, "Mathematics is such a language - all exact sciences speak this language."

\section{KEYWORDS}

Material point, angle, sign, algebra, formula, theorem, axiom, figure, algebra, equation, binary-applied, coordinate, motion.

\section{INTRODUCTION}

The development of mathematics in our country in 2020 has been identified as one of the priorities in the development of science. The resolution of the President Sh.M.Mirziyoyev "On measures to improve the quality of education and research in the field of mathematics" was also adopted. At one of the meetings dedicated to the development of science, our President said in his speech, "Mathematics is the basis of all exact sciences. A child who knows this science well will grow up to be smart, open-minded and successful in any field, "he said. There is a saying among our people: "Mathematics is a branch of science, be aware of its secrets!" (Qori Niyazi). Therefore, I think it is important to combine 
mathematics with other disciplines. Mathematics, which is based on arithmetic and logical problems, teaches students to solve various problems intelligently and apply them to life. If we link these issues to other disciplines, it will not only strengthen their knowledge of mathematics, but also their research skills, as well as their knowledge of other disciplines. We know that many problems in mathematics are related to physics. That is, you need to know both physical formulas and how to apply them. This encourages students to study physics in depth. All sciences are interconnected. But showing and proving it to the student, of course, depends on the pedagogical and scientific ability of the teachers. Teaching a student to search for and use something in the classroom is the basis for developing research skills.

\section{MAIN PART}

In the "review" section of the lesson, math teachers often give students independent work. This, of course, includes monitoring the student's knowledge. At the same time, giving students questions related to different subjects allows them to repeat and consolidate their knowledge of other subjects at the same time.

Question 1: When you add the date of Amir Temur's birthday to the date of the Battle of Mud, is the result divided by 3 ?

Here, students should recall their knowledge of history and know the sign of division into 3:

Solution: The year of the Battle of Mud is 1365

Amir Temur's birthday is 9

$1365+9=1374$
Division by 3: If the sum of the numbers is divisible by 3 , the number is divisible by $3: 1+3$ $+7+4=1515: 3=5$

Answer: Divided.

Problem 2: Find the residual number Au (gold) in Mendeleev's periodic table of chemical elements, which is 7, and express it according to the rule of residuality.

Here the student is required to know not only the Mendeleev table, but also the rule of residuals.

Solution: The serial number of Au (gold) is 79

$79: 7=11(2)$

The rule for the remainder is written as: $79=$ $11 \times 7+2$.

Problem 3: Add the number of bones in a human body to the square of 15 .

Here, too, the student is required to recall his or her knowledge of human anatomy and to construct an unknown equation and to know the square of a number.

Solution: The number of bones in the human body is 206

$152=225$

Unknown number - $\mathrm{x}$

$206+x=225$

$x=225-206$

$x=19$ Answer: 19

Problem 4: The equations of motion of a material point are given by $x=5+3 t$ and $y=3+$ 3t. What angle does the direction of motion of the material point make with the axis Ox? 
Given: $x_{0}=5 y_{0}=3$

Need to find: $a$-?

Problem solving:

The coordinates of the point at time $t=0$ are $x_{0}$ $=5 \mathrm{y}_{0}=3$

After some time, for example at $\mathrm{t}=1 \mathrm{~s}$, the coordinates of the material point

$\mathrm{x}_{1}=8 \quad \mathrm{y}_{1}=3+\sqrt{3}$

in the case of It is known that the angle formed by a straight line connecting the two positions of a point with the axis $O x$

$$
\operatorname{tg} \alpha=\frac{y_{1}-y_{0}}{x_{1}-x_{0}}
$$

determined by the expression. We perform calculations based on the value of the coordinates of the material point:

$$
\operatorname{tg} \alpha=\frac{3+\sqrt{3}-3}{8-5}=\frac{\sqrt{3}}{3}
$$

Answer: $\alpha=30^{\circ}$

\section{Q5: What is the meaning of the word algebra?}

Through questions like these, students become accustomed to memorizing not only arithmetic but also the meanings of related terms when studying mathematics.

Answer: Algebra is the European pronunciation of the word al-jabr in al-Khwarizmi's Al-jabr and al-muqabala, which means restoration in Uzbek.
Q6: From which language are the words axiom, theorem, formula, and figure derived?

Questions like these not only increase students 'interest in different languages, but also increase their interest in the history of the introduction of these terms into mathematics?

Answer: From the Greek

Q7: How many binary operations are there in mathematics and what are they called in English?

Testing students' knowledge of English and understanding the meaning of mathematical operations will not only broaden their worldview, but also increase their vocabulary.

Answer: There are 4 binary operations in mathematics, which are:

“+”-plus, “-_- minus, “×”- share, “־”- multiply.

\section{RESULTS}

From the above, it can be seen that there are many advantages to teaching one subject in relation to other subjects, and this can be applied to other subjects as well. A variety of similar topics can be used to increase students' interest in mathematics, as well as in other subjects. This will help strengthen their knowledge. Not only in mathematics, but also in other disciplines, it is possible to connect subjects through different questions. For example:

In a native language class, students can be taught to write numbers using letters and improve their mathematical literacy;

Geography, on the other hand, helps students broaden their worldviews and strengthen their knowledge of angles by identifying the angles 
at which countries are positioned relative to each other.

In the drawing class, drawing a complete composition using a variety of figures enhances students' imagination and increases their interest in learning, as well as the effective use of mathematical figures.

The result of starting the lesson with similar questions is to strengthen the knowledge of students in different subjects and improve the skills of the teacher.

\section{DISCUSSION}

In a debate with school teachers, it became clear that many teachers were limited to thinking only within their subject area. This allows students to think in detail so that they can solve a variety of problems in finding their place in the future. When we think about developing deep thinking skills in a student, we have to show him that all subjects are one. Discussions have shown that a good knowledge of a science does not always solve all kinds of problems in life.

\section{CONCLUSION}

It is clear from the above that if students are taught one subject and it is combined with different subjects, it will serve to strengthen their knowledge and increase their interest in learning more. This will help them to improve their research skills. So far, research is based on research. It is difficult to understand the world by knowing one science, especially not knowing the science of mathematics and not learning to apply it to life, which will lead to negative results in solving various problems in the future. Teaching math in conjunction with other subjects can help students solve life problems as well.

\section{REFERENCES}

1. Dadaboyev H., Amir Temur's military skills, T., 1996.

2. Nizamiddin Shamiy. Zafarnoma. -T., 1996;

3. Sharafiddin Ali Yazdiy. Zafarnoma. -T., 1994.

4. file:///C:/Users/ALFATECH.UZ/Downloads/fi zikadan_tipik_masalalar_va_ulardan_yechi mlari.pdf

5. http://matematika.uz/2017/02/matematikterminlar-va-belgilar/

6. https://www.google.com/search//

7. http://abdiyev.uz/bolinish-alomatlari/

8. https://www.lex.uz/docs/-4807552

9. Nasirov U.F., Ochilov Sh.A., UmirzoqovA.A. Analysis of Development of Low-Power and Man-Made Gold Deposits// International Journal of Academic and Applied Research (IJAAR)ISSN: 2643-9603 Vol. 4, Issue 4, April-2020,Pages:71-74.

10. Umirzoqov A.A., Jurayev S.J., KaramanovA.N. Economic and mathematical modeling of rational development of small-scale and man-made gold deposits// International Journal of Academic and Applied Research (IJAAR), Vol. 4, Issue 4, April - 2020, Pages: 75-77.

11. HayitovO.G.,UmirzoqovA.A.,Iskandarov J.R., Suvanov F.R. Prospects for the industrial use of coal in the world and its process of reproducing//Novateur Publication's JOURNALNX- A Multidisciplinary Peer Reviewed Journal, Volume 6, Issue 5, may-2020, Pages:240247.

12. KazakovA.N., UmirzoqovA.A., RadjabovSh.K., MiltiqovZ.D. Assessment of 
the Stress-Strain State of a Mountain Range// International Journal of Academic and Applied Research (IJAAR), Vol. 4 - Issue 6 (June - 2020), Pages:17-21.

13. Nasirov U.F., Ochilov Sh.A., Umirzoqov A.A. Theoretical Calculation of the Optimal Distance between Parallel-close Charges in the Explosion of High Ledges// Journal of Advanced Research in Dynamical and Control Systems - JARDCS, Vol. 12,07special issue, 2020, Pages: 2251-2257.

14. Umirzoqov A.A.,Karamanov A. N., Radjabov Sh. K. Study of the feasibility of using intermediate buffer temporary warehouses inside the working area of the Muruntau quarry// International Journal of Engineering and Information Systems (IJEAIS), Vol. 4, Issue 8, August - 2020, Pages 140-142.

15. Khayitov O.G', Umirzoqov A.A.,Bekmuratov A.O. Small Torch Progress In Prospects Gold Mining In Improving Countries// The American Journal of Interdisciplinary Innovations and Research, 2(09), 65-72. https://doi.org/10.37547/tajiir/Volumeo2Iss ueog-11.

16. Mirzarakhimov M.S., Iskandarov J.R.,Umirzoqov A.A.,Amanov T.S. Technology Of Modified Sodium-Aluminum Catalysts For Nitrogen Gas Purification Systems// The American Journal of Applied Sciences, 2(09),154-163. https://doi.org/10.37547/tajas/Volumeozlss ueog-24

17. Khakimov K.D., Eshonqulov U.K., Amanov T.S., Umirzoqov A.A. Complex Processing Of Lead-Containing Technogenic Waste From Mining And Metallurgical Industries In The Urals// The American Journal of Engineering and Technology, 2(09), 102-
108.

https://doi.org/10.37547/tajet/Volume02Iss ueo9-19 